University of New Orleans

ScholarWorks@UNO

Habsburg's Last War: The Filmic Memory (1918 to the Present)

\title{
Traces of Austria-Hungary and the First World War in Tsarist/ Soviet/Russian Cinematography
}

Verena Moritz

University of Vienna, University of Salzburg

Follow this and additional works at: https://scholarworks.uno.edu/hlw

Part of the European History Commons, and the Film and Media Studies Commons

(c) $($ ) $\odot$

This work is licensed under a Creative Commons Attribution-No Derivative Works 4.0

International License.

\section{Recommended Citation}

Moritz, Verena. "Traces of Austria-Hungary and the First World War in Tsarist/Soviet/Russian Cinematography." In Habsburg's Last War: The Filmic Memory (1918 to the Present), edited by Hannes Leidinger, 249-286. New Orleans: University of New Orleans Press, 2018.

This Chapter is brought to you for free and open access by the University of New Orleans Press at ScholarWorks@UNO. It has been accepted for inclusion in Habsburg's Last War: The Filmic Memory (1918 to the Present) by an authorized administrator of ScholarWorks@UNO. For more information, please contact scholarworks@uno.edu. 


\section{TRACES OF AUSTRIA-}

\section{HUNGARY AND}

\section{THE FIRST WORLD}

WAR IN TSARIST/

\section{SOVIET/RUSSIAN \\ CINEMATOGRAPHY}

Verena Moritz

The "Great War" and its "Comeback"

Against the backdrop of the $100^{\text {th }}$ anniversary, Russia's evident interest in the history of the years from 1914 to $1917 / 18$ was often perceived as a revival of a long suppressed and unwanted commemoration. In 2014, Russia, it seemed, rediscovered World War One. A "war forgotten" was remembered in various exhibitions, scientific and popular publications, illustrated books, TVdocumentary films, and even in the cinema. The way the Great War was exhibited, characterized, interpreted, and adapted for the screen in some cases more or less obviously corresponded to Russia's present-day self-portrayal as "home of the brave." Those brave men and women dominated the filmic narratives of WWI in 2014, and the general public must have been convinced that Russian soldiers' overwhelming patriotism and readiness to make sacrifices during WWI would result in a just and well-deserved 
victory, unless their enemies and allies were more or less satanic combatants (especially the German Empire) and deceitful traitors (France and Great Britain). According to this interpretation, Russia was abused by its allies and had to carry the major burden of the war. Obviously, an analogy between past and present was intended by the architects of a strong patriotism and a new patriotic culture in Vladimir Putin's Russia, which was ostracized by the USA and the European Union since at least its proceeding in the Crimea and in the Ukraine. The message is clear: Russia stood alone during the First World War, cheated by its allies and beaten only because of a revolution that was supported by the Germans, and it stands alone now, misapprehended and wrongly stigmatized by the rest of the world, which, without plausible reason, considers itself morally and ethically superior to Russia.

In 2014, on 1 August, when Putin inaugurated a monument to Russian soldiers of the First World War, he offered a "stab-in-theback explanation of Tsarist Russia's defeat and collapse," alluding "of course, to the Bolsheviks" who had been sent to Russia by the Germans. ${ }^{1}$ In doing this, the Russian President more or less adopted the perception of emigrated Tsarist officers who had interpreted the lost war as a "German-Bolshevik plot to destroy the nation.." In

1 Many thanks to J. Köstenberger and V. Denisov for their help regarding investigations for this article in Moscow.

Transliteration of Russian follows Library of Congress transliteration table.

Cf. Vladimir Socor, "Putin Re-Interprets Russia's Participation in the First World War," in Eurasia Daily Monitor Volume 11, no. 143 (2008). accessed Jan. 25, 2016, http://www.jamestown.org/single/?tx_ttnews\%5Btt_ news $\% 5 \mathrm{D}=42714 \&$ no_cache $=1$.

2 Aaron J. Cohen, "Oh, That! Myth, Memory, and World War I in the Russian Emigration and in the Soviet Union," Slavic Review 62, no. 1 (Spring 2003): 69-86, here: 74. 
any case, Putin spoke of "re-establishing the unbroken continuity of our history', incorporating the First World War's 'sacred memory' into the official accounts of Russia's history. [...] Amid its ongoing war against Ukraine, the Kremlin is reaching into history to recuperate yet another militarist narrative for popular consumption."3

There are many critical and stimulating analyses of Russia's past and current commemorative culture and the official conception of history that was repeatedly modified even in the Soviet era. ${ }^{4}$ After 1989 and the following fundamental changes that Eastern Europe, including the USSR, faced, a mere reversal of former interpretations by communist doctrines in regard to the history before and after the Bolsheviks seized power was an evident temptation for those countries. In post-Soviet Russia, historiography ran through various phases of reorientation. Putin's Russia obviously did not abandon communist interpretations of the past as a whole, in order to adapt them for its own purposes. As a result, Stalin, for example, remains the "father of the nation" who led Soviet people to a glorious victory against German barbarism between 1941 and 1945. Historiography and the conception of history in today's Russia are not free from contradictions. Still accepted communist interpretations of history and a reinterpretation of communist history as an antipode of former narratives are in juxtaposition with each other, but they somehow coexist. Moreover, popular interpretations of history introduce additional dimensions. But all of those variations that are initiated or accepted by official Russia, notwithstanding the lack of stringent reflections, share

\section{Ibid.}

4 See for example: Lars Karl and Igor J. Polianski, eds., Geschichtspolitik und Erinnerungskultur im neuen Russland (Göttingen: V\&R unipress, 2009); or Catherine Merridale, Night of Stone: Death and Memory in Twentieth Century Russia (London: Granta, 2000). 
the same intended purpose: the strengthening of patriotism, completed by the advice to distrust the world beyond the borders of Russia. ${ }^{5}$

In regard to the appraisal of the role of the Tsarist army, recent Russian fiction and documentary films have made a distinct turning away from former communist perceptions. Nonetheless, there are some striking continuities to Soviet cinema as, for instance, the near complete absence of Austria-Hungary.

\section{The Tsarist Empire and the War on the Screen}

After 1945, the so-called "Habsburg myth" played an important role in the process of identity in the Second Austrian Republic. While World War One itself was largely neglected in cultural

5 It has to be underlined that this text concentrates on the Russian official narratives in films on the First World War. There are, of course a lot of "deviant" interpretations including, for example, differentiated approaches by historians. In this respect, it has to be mentioned that, in 2012, Kees Boterbloem has examined Russian historiography of the First World War in regard of the Russian participation. He saw a lack of Russian-language monographs on Russia in WWI and reasoned that this lack had "much to do with the continued unease felt in Russia about the Great War." Boterbloem's result obviously differs from recent interpretations of the First World War and Russia’s role by official Russia today. Cf. Kees Boterbloem, "Chto delat'?: World War I in Russian Historiography after Communism," The Journal of Slavic Military Studies 25, no. 3 (2012), 393-408, accessed Feb. 1, 2016, DOI: 10.1080/13518046.2012.705655. On historiography of the Russian Revolution with an overview of current Russian interpretations of the Revolution see: S. A. Smith, "The Historiography of the Russian Revolution 100 Years on," in Kritika 16, no. 4 (Fall 2015), 733-749. 
avenues, completely uncritical depictions of Habsburg history presented the Austro-Hungarian Empire as role model for a peaceful coexistence of different nations and Franz Joseph I as the "the good old Kaiser." The Dual Monarchy was portrayed as an ideal state, and in regard of World War One, this "paradise" was only misled and abused by the Germans seeking world supremacy. After World War II, the Austrian people have become accustomed to such interpretations of the Habsburg past. They could not even imagine that Austria-Hungary was not seen in a similar way in other countries. Austrian feature films of the 1950s introduced soldiers of the "k.u.k." army as clumsy and harmless guys or as smart womanizers. The First World War on the screen, all in all, was either completely absent or presented as if there had been neither misery nor bloodshed, but only "Waltz" and "Schmaltz." It was unthinkable that soldiers of the Habsburg army had committed war crimes. ${ }^{7}$ In addition, historiography for decades focused on Germany, claiming that the militant Kaiserreich bear the chief responsibility for the war that started in summer 1914. The Danube Monarchy was either exculpated or more or less ignored. Until now, some historians complain, Austria-Hungary is rather perceived as victim of German warmongers than as autonomous player. ${ }^{8}$ In fact, there was already a movement to marginalize the Habsburg monarchy during the war, concentrating on its lack of

6 Sabine A. Haring, "Between the Topos of a 'Forgotten War' and the Current Memory Boom: Remembering the First World War in Austria," in Remembering the First World War, ed. Bart Ziino (London: Routledge, 2015), 207-222, here: 214-216.

7 See for example: Karin Moser, ed., Besetzte Bilder: Film, Kultur und Propaganda in Österreich 1945-1955 (Vienna: Verlag Filmarchiv Austria, 2005). 8 Lothar Höbelt, "Stehen oder Fallen?” Österreichische Politik im Ersten Weltkrieg (Vienna: Böhlau Verlag, 2015), 131. 
strength and its dependence on German economic and military support. The longer the war lasted, Entente powers tended to perceive Austria-Hungary as a pure appendix of German authorities, as "junior partner" of the Kaiserreich, which made important decisions without asking the young Habsburg Emperor Karl. Nevertheless, for Tsarist Russia, the Danube monarchy was its main adversary. While in 1914 Germany's main effort was concentrated against France, requiring approximately ninety percent of its manpower, Austria deployed the bulk of its forces against Russia. ${ }^{9}$

So, how did Tsarist cinematic propaganda portray the Danube monarchy, whose conflict with Serbia figured at the beginning of a European war that broadened to a world wide struggle? Whom did Russian cinema blame for the outbreak of the conflict that, in the end, swept away the Romanovs and their Empire? Who was deemed to be "worse" or more "condemnable"? The German Empire or the Danube monarchy? And was Russian film production able to comply with the requirements of an effective propaganda?

The war seriously affected Russian cinema: "On the eve of the conflict nearly 90 percent of film productions shown in Russia had come from abroad." ${ }^{10}$ Before the war, a large number of films distributed in Russia had been of German origin. After the outbreak of hostilities, French film companies in Russia especially

9 Timothy C. Dowling, "Eastern Front," in 1914-1918-online: International Encyclopedia of the First World War, ed. Ute Daniel et al. (Berlin: Freie Universität Berlin 2014), DOI: http://dx.doi.org/10.15463/ ie1418.10316.

10 Alexandre Sumpf, "Film/Cinema (Russian Empire)" in 1914-1918-online: International Encyclopedia of the First World War, ed. by Ute Daniel et al. (Berlin: Freie Universität Berlin, 2014), DOI: http:// dx.doi.org/10.15463/ie1418.10383. 
benefited. ${ }^{11}$ Besides, the Tsarist Empire saw a growing number of Russian companies and "the strengthening of national champions, as the Khanzhonkov, Drankov and Ermol[']ev Studios." ${ }^{12}$ Native film production increased rapidly. On the other hand, "it would be a mistake to underestimate the profound influence of Western European filmmaking had overall in Russian filmmakers and audiences."13 German companies, however, were forced to shut down their production, and German theater owners and distributors were exiled. In 1915, all German films were banned. ${ }^{14}$

Tsarist propaganda identified Germany as a responsible aggressor and as the most dangerous enemy, "the one against which the greatest patriotic efforts had to be directed." ${ }^{15}$ Germans turned out to be the main target of people's anger in Russian metropoles, and anti-German riots seemed to express the degree of hate toward the enemy, including the German minority in Russia. ${ }^{16}$ Spy mania was widespread already before the war and explosively increased during the July Crisis 1914. German speaking people, including Jews, were

11 In 1914, ninety percentof the films distributes internationally in the world were French; Michael Wood, Film: A Very Short Introduction (Oxford: University Press, 2012), 48

12 Sumpf, "Film/Cinema (Russian Empire)." On the Russian "Movie Moguls" see: Louise McReynolds, Russia at Play: Leisure Activities at the End of the Tsarist Era (Ithaca: Cornell University Press, 2003), 269-276.

13 Denise J. Youngblood, The Magic Mirror: Moviemaking in Russia 1908-1918 (Madison: The University of Wisconsin Press,1999), 13.

14 Hubertus F. Jahn, Patriotic Culture in Russia During World War I (Ithaca: Cornell University Press, 1995), 152.

15 Jahn, Patriotic Culture, 173.

16 On the riots in Moscow of 26-29 May 1915 see: Eric Lohr, "Patriotic Violence and the State: The Moscow Riots of May 1915," in Kritika 4, no. 3 (Summer 2003), 607-626. 
considered the prime suspects by Tsarist counterintelligence, and "private citizens flooded government agencies with denunciations of suspected spies." ${ }^{17}$ Recently, however, Russian historians have questioned if Germanophobia would have emerged that intensely without the massive efforts of propaganda especially in 1914-15. ${ }^{18}$

Russian propaganda had to go all out to shape a convincing concept of the enemy. Finally, "convincing" meant to present a primitive and distorted image. Germany and its "Kaiser" were demonized, and Wilhelm was portrayed as the "Antichrist."19 In a feature film of the same title (Antichrist), the German Emperor acted like a real

17 Jonathan W. Daly, "Security Services in Imperial and Soviet Russia," in Kritika: Explorations in Russian and Eurasian History 4, no. 4 (Fall 2003), 955-974, here: 969.

18 See respective deliberations in contributions of: Wladimir Fedjuk, "Der Kampf gegen die 'deutsche Überfremdung' in der russischen Provinz," in Verführungen der Gewalt: Russen und Deutsche im Ersten und Zweiten Weltkrieg, ed. Karl Eimermacher and Astrid Volpert (Munich: Wilhelm Fink Verlag, 2005), 95-119; Boris Kolonizkij, "Metamorphosen der Germanophobie: Deutschland in den politischen Konflikten der Februarrevolution," in Verführungen der Gewalt: Russen und Deutsche im Ersten und Zweiten Weltkrieg, ed. Karl Eimermacher and Astrid Volpert (Munich: Wilhelm Fink Verlag, 2005), 121-144; Dimitrij Olejnikow, "Von Ritterlichkeit zu Verachtung: Auswirkungen des Ersten Weltkriegs auf das Verhältnis zu den Deutschen," in Verführungen der Gewalt: Russen und Deutsche im Ersten und Zweiten Weltkrieg, ed. Karl Eimermacher and Astrid Volpert (Munich: Wilhelm Fink Verlag, 2005), 179-204.

19 Jekaterina Chochlowa, "Vom Dialog zu Konfrontation: Russischer und deutscher Film zwischen den Weltkriegen," in Stürmische Aufbrüche und enttäuschte Hoffnungen: Russen und Deutsche in der Zwischenkriegszeit, ed. Karl Eimermacher and Astrid Volpert (Munich: Wilhelm Fink Verlag, 2006), 927-952, 930. 
monster, brutal and completely immoral..$^{20}$ According to the belief of some Russian peasants, he was even drinking human blood. ${ }^{21}$ The film was very popular and became a tremendous box office hit, as an exhibitor from Moscow wrote in the Kine-zhurnal. ${ }^{22}$ Wilhelm was a "negative hero," a character that united all what was considered to be evil. He was blamed to be responsible for the shocking attacks on Belgian civilians committed by his soldiers. In Liliia Bel'gii (The Lily of Belgium, 1915, directed by Ladislas Starevich), an animated film that is perceived as a masterpiece of early Russian cinematography, German soldiers figured as "barbaric Huns" who "raped" Belgium. ${ }^{23}$ The film journal Ekkran Rossii called the film an "allegory" of Belgium's "suffering." ${ }^{24}$ Far from "allegory," however, was the plot of Dykhanie antikhristov (The breath of the antichrists), which was released in 1915 by the company G.I. Libken. In this film, German soldiers are not only killing Russian prisoners of war, but also raping women, beating children, and burning down peaceful villages. The journal Sine-fono predicted a huge success of Dychanie antichristov. ${ }^{25}$

"War terror films played extensively on the audience's fascination with the unknown and therefore dangerous aspects of the

20 Jahn, Patriotic Culture, 166.

21 Sine-fono, no. 13 (April 25, 1915), 90.

22 Sine-fono, no. 14-15 (May 23, 1915), 78-79.

23 Sumpf, "Film/Cinema (Russian Empire)."

24 Ekran Rossii, no. 1 (1916), 20.

25 Sine-fono, no. 19-20 (Aug. 22, 1915), 66. See also pictures from the film in: Vestnik Kinematografii, no. 114 (1915), 15-16, 32, 51, 53. There was a Russian film - perhaps-Dychanie antichristov that showed German nurses, searching through the battlefields and stabbing Russian wounded soldiers; Arthur Ponsonby, Absichtliche Lügen in Kriegszeiten: Eine Auswahl von Lügen, die während des Ersten Weltkrieges in allen Völkern verbreitet wurden (Seeheim: Buchkreis, 1967), 135. 
war. The psychological function was clearly more important than the historical authenticity of the episodes. In this respect, it should be noted that 'German horrors' were already being advertised in a film produced at the very outbreak of the war, before any atrocities had been reported." ${ }^{26}$ It has to be noted that the Russian audience, seemingly already before the war, preferred more dramatic and morbid films than the Western moviegoers: Russia’s movie studios had "manufactured dreams that audiences in other cultures would have considered nightmares." ${ }^{27}$ Obviously, people found "unhappy endings" more consolatory than "happy endings" that were far from real life. ${ }^{28}$ This, perhaps, helps to understand why in 1916 a film with the depressing title The Poor Chap Died in an Army Hospital was one of the most viewed picture in wartime Russia. ${ }^{29}$

26 Jahn, Patriotic Culture, 166. "All the belligerents in World War One employed atrocity propaganda associated with the enemy and, as a result, stereotypes emerged that had been largely developed in the period leading up to the outbreak of war. The recognition of stereotypes is an important part of understanding the use of anti-symbols and the portrayal of the enemy in propaganda"; David Welch, "Depicting the enemy," British Library, accessed Feb. 2, 2016, http://www.bl.uk/world-war-one/articles/depicting-the-enemy. See also: David Welch and Jo Fox, eds., Justifying War: Propaganda, Politics and the Modern Age (Basingstoke: Palgrave Macmillan, 2012).

27 McReynolds, Russia at Play, 290. See also: 276.

28 See also: Richard Stites, Russian Popular Culture: Entertainment and Society Since 1900 (Cambridge: University Press, 1992), 33-34. With explanations for the Russian type of "melodrama": Schamma Schahadat, "Leidenschaft und Ökonomie: Das russische Stummfilm-Melodrama zwischen Fin de Siècle und Moderne," arcadia: International Journal of Literary Culture 44, no. 1 (Jan. 2009): 137-186, here: 160 and 140-142.

29 Sumpf, "Film/Cinema (Russian Empire)." 
"Fear and horror" attracted an audience that wanted to learn what the enemy was like. German war crimes flourished in all Russian arts. Some popular Russian feature films interestingly mainly focused on violence committed on the French front rather than on the situation in Galicia, East-Prussia, or Armenia. ${ }^{30}$ But, by only skimming over the pages of Russian film journals, ${ }^{31}$ one will realize that there are some feature films, like the above mentioned Dykhanie antikhristov and various documentary films, that dealt with atrocities on the Russian Western Front. The latter were shown in various newsreels (kinokhronika), produced, for example, by the Skobelev Committee, which, in 1914, "had obtained exclusive rights from the emperor to film on the front lines, to raise funds for soldiers wounded in combat with the sale of the footage." ${ }^{32}$ The Skobelev Committee, however, was ill-equipped and underfunded. Less than a dozen cameramen tried to get pictures of military operations and life at the front lines. Hence, historians claim, the Skobelev Committee was not able to provide a visual record of the war on the Russian Western Front and that, consequently, Russian moviegoers learned more about what was

30 Ibid. and Alexandre Sumpf, "In Szene gesetzt: Der Erste Weltkrieg im russischen und sowjetischen Kino," Osteuropa 64, no. 2-4 (FebruarApril 2014): 339-350, here: 340; Kine-zhurnal, no. 19-20 (Oct. 18, 1914).

31 On Russian film journals see for example: Natascha Drubek, Russisches Licht: Von der Ikone zum frühen sowjetischen Film (Vienna: Böhlau, 2012), 117.

32 Sumpf, "Film/Cinema (Russian Empire)." On the history of the film department of the Skobelev-Committee see also: G. E. Malysheva, "K istorii kinematograficheskoi dejatel'nosti Sokobelevskogo komiteta 19131914 gg. Opyt i metodiki issledovatel'skoi raboty spetsialistov Rossiiskogo gosaudarstevennogo archiva kinodokumentov (RGAKFD)," in Vestnik archivista, no. 1 (2012): 3-17. 
going on at the theaters of War of their allies. ${ }^{33}$ Undoubtedly, footages delivered by France or Great Britain outnumbered Russian newsreels to give an impression of the war. But, obviously, at least in 1914-15, Russian feature as well as documentary films on war crimes committed by the enemies did not completely omit the Western Front. After all, to show enemy barbarity on the screen was a matching part to press propaganda, where news about cruelties of the adversary had become ubiquitous. ${ }^{34}$

Violence against Tsarist prisoners of war in Austria-Hungary was picked up by Russian propaganda, which published various pamphlets or reports of soldiers who succeeded in escaping. It is not amazing, that atrocities committed by Austrian-Hungarian soldiers did also reach the screen. ${ }^{35}$ Only few weeks after the outbreak of war the Kine-zhurnal announced the release of the feature film Tsivilizovannye varvary (Civilized barbarians), where Austrian soldiers arrested a defenseless young woman and only at the last moment were restrained from shooting an old man who was suspected to be a spy. Interestingly, at the end of the description of the film in the Kine-zhurnal, the old man is dooming the

33 Peter Kenez, Cinema and Soviet Society, 1917-1953 (New York: Cambridge University Press,1992), 22.

34 Cf. Laurent Véray, "Cinema," in The Cambridge History of the First World War, vol. 3, Civil Society, ed. Jay Winter (Cambridge: Cambridge University Press, 2014), 475-503, here: 492. See also: World War I and Propaganda, ed. Troy R.E. Paddock (Leiden: Brill, 2014), 1.

35 On atrocities committed by Austro-Hungarian soldiers and the "image” of them among Russians see: Elena S. Senjavskaja, "Die Völker Österreich-Ungarns im Ersten Weltkrieg aus der Sicht des russischen Gegners," in Jenseits des Schützengrabens: Der Erste Weltkrieg im Osten. Erfahrung - Wahrnehmung - Kontext, ed. Bernhard Bachinger and Wolfram Dornik (Innsbruck: Studienverlag, 2013), 325-340. 
"German hangmen" ("palacham-nemtsam") and not the Austrian ones. ${ }^{36}$ Another movie, which was also produced by the company of A. O. Drankov, is described in the same issue of the mentioned zhurnal and deals with the very first period of the war, too: Za tsarja $i$ otechestvo ili liudi-brat'ia (For Tsar and fatherland). It shows the situation at the frontier to Austria-Hungary shortly after the hostilities had started. The Austrians are brutal, but they act cowardly, unsuccessfully trying to incite the different nations against the Russians: "Russians, Jews, Georgians, Ingush: all are fighting to save the home country." ${ }^{37}$ Generally, the Austrian brutes are of German or Polish origin. Concentrating on those nations, the propaganda corresponded with existent animosity and distrust. It was plausible that the scene of anti-Austrian feature films was mainly situated in the neighboring Austrian crownland Galicia, with its multifaceted ethnic conflicts.

Due to Germany's part as the aggressor to blame the most for the outbreak of war it makes sense that Russian wartime feature films mostly focused on Germany and the Germans, who were transgressing "all moral and religious bounds." ${ }^{38}$ On the other hand, there are no studies on Russian film production in wartime that are trying to find out if there were significant differences in presenting either the German or the Austrian or the GermanAustrian (German speaking Austrians/Deutschösterreicher) enemies on the screen. A first and rough analysis of Russian wartime feature films, based on Russian film journals published between 1914 and 1917 and filmographies for this period, supports the assumption that patriotic feature films dealing with "anti-German plots" predominate. But is has to be stated that the

36 Kine-zhurnal, no. 15-16 (Aug. 23, 1914): 33.

37 Ibid.

38 Jahn, Patriotic Culture, 165. 
"German preponderance" in comparison with Austria-Hungary's presence is less striking than supposed-at least at the beginning of war. ${ }^{39}$

Tsarist filmic propaganda used traditional stereotypes of the enemy states and intensified and even exaggerated them to the point of a burlesque: "As in other warring nations, enemy leaders became convenient personifications and focal points of broader sets of clichés. [...] Images of a weak and crumbling empire, expressing imperial rivalry with Austria, were projected onto the figure of the old and frail Franz Joseph." ${ }^{40}$ But did the Habsburg monarchy, which was considered to be weak and damned to crumble, appear to be less dangerous than the "German huns"? And did Russian cinema portray Franz Joseph in a similar way as it did German Kaiser Wilhelm?

In 1916, when the Kine-zhurnal indicated that there were about 4,000 motion picture theaters in Russia, with two million moviegoers a day, ${ }^{41}$ a film about the tragedy of the Austrian crown prince Rudolf and his concubine Mary Vetsera was advertised. ${ }^{42}$ Mariia Vechera, produced by the company Drankov, was obviously released already in the year before and announced as film

39 See for instance: Velikii kinemo: Katalog sokhranivshikhsia igrovykh fil'mov Rossii 1908-1919 (Moscow: Novoe literaturnoe obozrenie, 2002); V. Vishnevskii, Dokumental'nye fil'my dorevoliutsionnoi Rossii 1907-1916 gg. (Moscow, 1996); Ven. Vishnevskii, Khudozhestvennye fil'my dorevoliutsionnoi Rossii (Filmograficheskoe opisanie) (Moscow: Goskinoizdat, 1945); S. S. Ginzburg, Kinematografiia dorevoliutsionnoi Rossii (Moscow, 1963); Sovetskie khudozhestvennye fil'my: Annotirovannyi katalog (Moscow: Iskusstvo, 1961).

40 Jahn, Patriotic Culture, 173.

41 Kine-zhurnal, no.15-18 (1916): 82.

42 Kine-zhurnal, no. 19-20 (1916): 104. 
about a "secret affair in the live of a foreign court."43 In this picture, retelling the history of the unhappy son of Emperor Franz Joseph who killed his concubine and then committed suicide, the audience is confronted with an abstruse version of the tragedy: the pregnant Mary Vetsera and her blue-blooded lover Rudolf are shot by officers who were instructed by Franz Joseph to arrest Rudolf's concubine. The death of the old monarch's only son buries the hopes of a whole Empire. Franz Joseph and Empress Elisabeth figure as broken parents. One can suppose that there is some sort of compassion toward the aged "Kaiser," who had lost his son under such tragic circumstances. ${ }^{44}$

In 1932, the magazine Proletarskoe kino analyzed Russian wartime propaganda and asserted that the Germans had been portrayed as barbarians, whereas the Austrians had been described as cowards and scoundrels. ${ }^{45}$ As I have already shown in connection with Russian film productions shortly after the outbreak of war, there are some examples that illustrate that Austrians were considered to be cruel and merciless as well, notwithstanding portraying Franz Joseph as an old and broken-hearted man. In fact, there was no need for Russian propaganda to present the Austrian enemies as less damnable than the German ones. Above all, the oppression of Russia's "Slavonic brothers" by Habsburg authorities served as a drastic example of the wickedness of the neighbor. This, for example, correlated with a film that was released in 1916 and advertised by the company Gomon as "vigorous drama." Vokovakh Avstrii (In Austria's chains) follows the experience of young Anton, living in Galicia. An Austrian named Prokop wants to get rid of him because he desires

43 Kine-zhurnal, no. 13-14 (1915): 116.

44 Kine-zhurnal, no. 19-20 (1916): 112-113.

45 V. Sorokin, "Kino in vojna," in Proletarskoe kino, no. 9 (1931): 48-53, here: 50 . 
Anton's girlfriend, Praskeda. Because of Prokop's influence, Anton is enlisted by the Austrian army. Now Anton is full of hatred against Austria-Hungary. He decides to desert and fight against the Habsburg monarchy. ${ }^{46}$ Finally, he is arrested by Austrian authorities and sentenced to death. His lady lover Prakseda goes mad and is killed by Anton's uncle to "save" her from Austrian cruelties. The advertising pictures in Kine-zhurnal show a Russian soldier (probably Anton) who is executed by Austro-Hungarian soldiers. ${ }^{47}$

Austrian brutality is also the main subject in a feature film on Czechs who had acquired Russian citizenship and united in a "legion of victory or death." The film, titled Druzhina pobedy ili smerti, showed the tragic fate of "Czech heroes" who fought against Austrian oppressors and had to face the death penalty when being caught by the Austrians. In fact, "some 10 per cent of Czech prisoners volunteered" for the Czechoslovak Legion in Russia. ${ }^{48}$ The film Druzhina pobedy ili smerti was announced as an impressive example for the struggle between Slavs and Germans. ${ }^{49}$ Furthermore, Slava nam - smert' vragam (Glory to us, death to the enemy), a film directed by Evgenjj Bauer and produced by A. Khanzhonkov, showed that heroism could overcome apparently invincible enemies: Disguised as an Austrian nurse, the heroine of this film stabs a love-crazed Austro-Hungarian officer to get an important secret message. In the end, she is decorated with military honors, after having handed over the secret documents to Russian troops. ${ }^{50}$ However, Slava nam - smert' vragam did not

\footnotetext{
46 Sine-Fono, no. 6-7 (Jan. 10, 1915): 67.

47 Kine-zurnal, no. 21-22 (Nov. 1916): 76 and 131.

48 Aviel Roshwald, Ethnic Nationalism and the Fall of Empires: Central Europe, Russia and the Middle East, 1914-1923 (London: Routledge, 2001), 148.

49 Sine-fono. no. 1-2 (Oct. 18, 1914): 38.

50 Stites, Russian popular culture, 35.
} 
reveal "before the audience ... 'scandalous and blatant horrors," with the exception of "almost colorless, grey episodes in which the nightmare of reality appears so clearly." ${ }^{1}$

Whereas the treason of former Austrian citizens was interpreted as a heroic act, espionage was either damned or appreciated, depending on the question who was spying and for whom: "Espionage and treason fitted nicely into a wave of detective novels and films that swept over the Western world and Russia alike." ${ }^{52}$ Many of these films merely adapted the war to an established taste, but some contained more or less elaborate patriotic messages. In fact, there were a lot of spy films that focused on German espionage in particular. ${ }^{53}$ The writer and son of Ekaterina Breshko-Breshkovskaia, Konstantin Breshko-Breshkovskii, succeeded as the author of some of those spy films, where male and female spies were trying to obtain secrets about Russian warfare. Breshko-Breshkovskii appeared as a screenplay writer for a film, titled Grafinia-shpionka (avstrijskaia avantiura). The film was released only few days before the war broke out, and unlike the majority of spy films, concentrated on espionage of Austrian and not German provenience. ${ }^{54}$

Spy films perfectly suited to a popular taste that, from the very beginning of the war, preferred plain entertainment and "the usual fare that had been popular before the war." ${ }^{55}$ Feature films with war themes "were the crude and sensationalist fruits of savage competition among film companies. Superlatives of terror, baseness,

51 Cit. Silent Witnesses. Russian Films 1908-1919/Testimoni silenziosi. Filmi russi 1908-1919, ed. Paolo Cheerchi Usai et al. (Pordenone: Edizione Biblioteca dell'Immagine/British Film Institute, 1989), 236.

52 Jahn, Patriotic Culture, 163.

53 See: Proektor, no. 11-12 (June 15, 1916): 8.

54 Kine-zhurnal, no. 15-16 (Aug. 23, 1914): 10-11.

55 Jahn, Patriotic Culture, 154. 
brutality, and schmaltz advertised artistically weak and overhastily lubok farces, patriotic spy and detective movies, nationalist love affairs and melodramas, and thrilling and apocalyptic 'terror films." 56

While, in 1915, the Skobelev committee praised itself for a realistic depiction of war in its documentary films, ${ }^{57}$ escapism increased as the war dragged on. ${ }^{58}$ The retreat of the Russian army as a result of Austro-German victories in 1915 left its marks on the Russians. It was perceived as a disastrous and disgraceful defeat, destroying the vision of a glorious victory. Patriotism "became more differentiated, simultaneously reflecting separate and even disparate loyalties within society." ${ }^{59}$ This development as a matter of course affected Russian film production, too. According to Denise J. Youngblood from "1 August 1914 to the end of the year, nearly half of films made (50 to 103) concerned the war, but in 1916 the figure was only 13 titles out of a total of 500. This startling fact reflects in large part the extreme disaffection of the public from the government and the war effort-as well as the

\section{Ibid., 168.}

57 Sumpf, “In Szene gesetzt," 339-343; Ekran Rossii, no. 1 (1916): 23.

On the problem of "authenticity" see also: David Williams, Media, Memory, and the First World War (Montreal: McGill-Queen's University Press, 2009), 110; Horst Tonn, "Der Erste Weltkrieg im amerikanischen Film," in Der Erste Weltkrieg in der populären Erinnerungskultur, ed. Barbara Korte, Sylvia Paletschek, and Wolfgang Hochbruck (Essen: Klartext, 2008), 169180.

58 The fact that Russian movie-goers preferred plain entertainment interested also Soviet "experts" for cinema. See for example: K. Shutko, "Imperialisticheskaia voina i dorevoliucionnoe kino. Obzor kinozhurnalov 1915-1917," in Sovetskoe kino, no. 8 (September 1934): 31-34.

59 Jahn, Patriotic Culture, 171. 
government's inability to organise cinematic propaganda." ${ }^{60}$ Peter Kenez comes to similar conclusions, considering the absence of a centralized propaganda institution: "The outbreak of the war made a difference in the character of the Russian feature film not as result of the purposeful intervention of the government, but because the filmmakers shared the momentary enthusiasm for war, and because they believed that their audiences would pay to see patriotic films." ${ }^{16}$ But, as soon as the enthusiasm faded, and it became clear that the war was not going to become a short and glorious combat, Russian film production turned to more promising genres.

In the period between the two Revolutions of 1917 not only the Skobelev committee was preoccupied with its reorganization; ${ }^{62}$ the whole film and cinema business was seeking re-orientation: "Ideology entered Russian cinema with the Fall of the Romanov dynasty in February 1917. A brief look at titles of some of the films released in that year is sufficient to grasp the anti-monarchist and radical public mood: Dark Forces: Grigorii Rasputin and his Associates; In the Clutches of Judas; Governmental Deception; The Revolutionary, The Bourgeois, Enemy of the People." ${ }^{63}$ The Kinezhurnal in June 1917, for instance, announced the production

60 Denise Youngblood, "A War Forgotten: The Great War in Russian and Soviet Cinema," in The First World War and Popular Cinema, ed. Michael Paris (New Brunswick, N.J.: Rutgers University Press, 2000), 172181,173; Denise Youngblood, Russian War Films: On the Cinema Front, 1914-2005 (Lawrence: University Press of Kansas, 2007), 14.

61 Peter Kenez, Cinema and Soviet Society, 18.

62 Kine-zhurnal, no. 5-6 (1917): 22 and 23; Richard Taylor, The Politics of The Soviet Cinema 1917-1929 (Cambridge: Cambridge University Press, 1979), 21.

63 David C. Gillespie, Russian Cinema (Edinburgh: Longman Publishing Group, 2003), 103. 
about the last Tsar and his "bloody reign." ${ }^{64}$ However, 1917 was more a caesura for film producers than for the audience itself, who still preferred entertainment films. ${ }^{65}$

There was a noticeable uncertainty in regard to the future of Russian film production. By the end of 1917, rumors about Bolshevik plans to nationalize Russian cinematography alarmed, as the Kine-zhurnal stated, everyone who was in some way involved in the production or distribution of movies. ${ }^{66}$ Starting in May 1918, the Bolshevik newsreel Kino-Nedelja from time to time recalled the World War by showing "remains" of the conflict: for example, German and Austro-Hungarian POWs departing or homecoming Russian POWs. ${ }^{67}$ After the October Revolution, the exodus of film companies started. Nonetheless, the box office results in 1917 "broke previous records" and improved "by 33 percent 1916, which was itself also a banner year." ${ }^{68}$

64 Kine-zhurnal, no. 5-6 (March 30, 1917): 24-25.

65 Taylor, The Politics of The Soviet Cinema, 15-25.

66 Kine-zhurnal, no. 17-24 (1917): 48.

67 The "Austrian Film Museum" has published its flagship online video project: "Kino-nedelja - Online Edition." 14 of the original 43 issues of the early Soviet newsreel series "Kino-nedelja" (Kino-Week) survived in the Austrian Film Museum's collection. The newsreels, which date from the years 1918 and 1919, are not merely significant for their depiction of life in the young Soviet Russia during the civil war, but also because they represent Dziga Vertov's first contribution to cinema. See: Filmmuseum, accessed March 12, 2016, https://www.filmmuseum.at/sammlungen/special collections/sammlung dziga vertov/kinonedelja online edition.

68 Denise J. Youngblood, The Magic Mirror, 14. 


\section{The Interwar Period}

After 1918-19, the collapsed Russian film industry was reborn as Bolshevik cinema. The production of films on revolutionary topics replaced those on usual war themes that anyway had reached only a decreasing audience since 1915. Denise Youngblood, Karen Petrone, and Alexandre Sumpf, in their studies on Russian and Soviet Commemoration of World War One, have also examined the role the Great War played in Soviet interwar film productions. ${ }^{69}$ Sumpf, for instance, refers to Soviet montage films like Esfir Shub's The Fall of the Romanov Dynasty (1927) or Evgenii Iakushin's The World War (1929). ${ }^{70}$ Significantly, in The Fall of the Romanov Dynasty, the assassination of Archduke Franz Ferdinand was not even mentioned, while concentrating especially on the social consequences of the conflict. ${ }^{71}$ According to Sovetskii Ėkran, the enemies of Russia in "The World War" simply appeared as "imperialists." The audience, however, was confronted with an elephant from a "German zoo" who had to replace a railroad engine. ${ }^{72}$

Denise Youngblood emphasizes "the extremely tangential role the Great War played" in revolutionary films like, for example, Eisenstein's famous October (1928). She stresses that many of the revolutionary films included only some references to World War One, "but by no stretch could they be labelled 'war films' in

69 For comparison see for instance: Claudia Sternberg, "Der Erinnerungsdiskurs im Spielfilm und Fernsehspiel," in Der Erste Weltkrieg und die Mediendiskurse der Erinnerung in Großbritannien, ed. Barbara Korte, Ralf Schneider, and Claudia Sternberg (Würzburg: Königshausen \& Neumann, 2005), 243-342.

70 Sumpf, "Film/Cinema (Russian Empire)."

71 Ibid.

72 Sovetskij Ekran, no. 30 (July 30, 1929): 4. 
the sense that European and American directors were making films about the world war that focused on the trials of soldiers at the front and in the trenches."73 The only important Soviet film of the 1920s "in which Word War One battle time occupies significant screen time" is, as Youngblood states, Aleksandr Dovshenko's film Arsenal (1929). ${ }^{74}$ In regard to productions of the 1930s that were dealing with the war, she concentrates on an analysis of Boris Barnet's Okraina (1932).$^{75}$ Aleksandre Sumpf, beyond Okraina and Arsenal, quotes other Soviet interwar feature films "wholly or partially about the Great War." Among those are: Comrade Abram (1919), Enemies (1924), Women of R'iazan (1929), God of War (1929), Her Way (1929), Merchants of Glory (1929), Cities and Years (1930), Doomed (1930), Sniper (1931), Quiet Flows the Don (1931), Three Soldiers (1932), and The First Platoon (1933). ${ }^{76}$

Karen Petrone is convinced that "World War I memory was an integral part of Soviet culture in the 1920s, even if the war was often viewed as mere prelude to the Revolution." 77 The fact that, between 1919 and 1933, the Soviet film industry produced at least

\footnotetext{
73 Youngblood, A War Forgotten, 175.

74 Ibid., 176.

75 The title is translated by Youngblood as "Borderlands" and by Sumpf as "Outskirts."

76 Sumpf, "Film/Cinema (Russian Empire)." 2014, some of these films were shown in the course of a scientific conference in Moscow that was dedicated to the commemoration of the First World War in Russian/Soviet movies. See: “Первая мировая война в зеркале кинематографа," tvkultura.ru, accessed Aug. 3, 2015, http://tvkultura.ru/article/show/article_id/120085.
}

77 Karen Petrone, The Great War in Russian Memory (Indianapolis: Indiana University Press, 2011), 243. 
twenty-one fictional and documentary films ${ }^{78}$ is an endorsement of Petrone's assessment in this regard.

It is obvious that the majority of those Soviet films quoted above were produced at the same time, when films like Westfront 1918. Vier von der Infanterie (1930, directed by G.W. Pabst) or above all the American film adaptation of Erich Maria Remarque's novel, All Quiet at the Western Front (1930), ${ }^{79}$ excited and provoked the audiences in Europe.

Again, there is the question of whether there are any traces of Austria-Hungary's participation in the war in Soviet films on the First World War of this period. Not surprisingly, neither Sumpf and Youngblood nor Petrone are interested in identifying the "enemy" in the respective productions either as Germans or as Austrians/ Hungarians. They, more or less, "silently" accept that Soviet films concentrated on the Germans, often portrayed as proletarian comrades, abused by imperialism and nationalism and eventually "enlightened" and purified by experiencing communist solidarity. Obviously, only in Te, kotorye prozreli (Those who were enlightened, 1930) is the audience confronted with soldiers from the Habsburg monarchy. According to a short plot description, the film deals with the events on the Western front in March 1917, ending in friendship between Russian and Hungarian soldiers. The film,

78 In his article on war disabled on the screen Sumpf refers to the "production of at least 21 Soviet fictional and documentary films" between 1919 and 1933; Alexandre Sumpf, "War Disabled on Screen: Remembering and Forgetting the Great War in the Russian and Soviet Cinema, 19141940," in First World War Studies 6, no. 1 (2015): 57-59, here: 58, DOI: 10.1080/19475020.2015.1047889.

79 Verena Moritz, “Krieg," in Kampfzone Kino: Film in Österreich 19181938, ed., Verena Moritz, Karin Moser, and Hannes Leidinger (Vienna: Filmarchiv Austria, 2008), 255-276, here: 265-269. 
with its alternative titles Janosh vernëtsja domoj or Janosh priedet zaftra (Janosh is coming home [tomorrow]) is, it seems, a more than rare example of the Danube monarchy's "life after death" in Soviet interwar film productions. ${ }^{80}$

In sum, in many Soviet films on the First World War, there is, as A.M. Belogor'ev points out, an absence of "the enemy." ${ }^{81}$ Cinema was not able to make comprehensible what World War One was about. The First World War more and more became "an ahistorical symbol of imperialist" and, finally, "fascist, war." ${ }^{22}$ Nevertheless, the "imperialists" are Germans rather than Austrians, and in regard to "fascists," the connotation is obvious. Moreover, it has to be taken into account that due to Germany's role concerning Lenin's return to Russia and its intransigence in regard to the peace negotiations, the anti-German climate

80 Repertuarnyi ukazatel' dejstviiushchego fonda kinokartin: 1. Spisok khudozhestvennykh kinokartin na 1 marta 1940 g., (Moscow: Goskinoizdat, 1940), 58; Repertuarnyi ukazatel': Kinorepertuar. Pod redakciei P. A. Bljachana. Sostaviteli: A. I. Kacigras i A.S. Rozhdestvennskii (Moscow: Gosudarstvennoe izdatel'stvo khudozhestvennoj literatury, 1934), 90; and a description in: “Te, которые прозрели," my-hit.org, accessed Jan. 2, 2016, https://my-hit.org/ film/400411/; “Те, которые прозрели," kino-teatr.ru, accessed Nov. 26, 2015, http://www.kino-teatr.ru/kino/movie/sov/13701/annot/print/.

81 A. M. Belogor' ev, "Pervaia mirovaia voina v zerkale otechestvennogo kinematografa," in Istoricheskaia Ekspertiza, no. 1-2 (2015): 143-157, here: 153 .

82 Aaron J. Cohen, "Oh, That! Myth, Memory, and World War I in the Russian Emigration and in the Soviet Union," in Slavic Review 62, no. 1 (Spring 2003): 69-86, here: 79. See also: Aaron Cohen, "Commemoration, Cult of the Fallen (Russian Empire)," in 1914-1918-online: International Encyclopedia of the First World War, ed. Ute Daniel et al. (Berlin: Freie Universität Berlin, 2014), DOI: http://dx.doi.org/10.15463/ie1418.10421. 
in revolutionary Russia even increased, whereas the Habsburg monarchy appeared as a more or less moderate contingent that was ready to accept compromises. This perception continued to exist and, as a result, dominated Soviet Russia's attitude towards "Germans and Austrians," too. Furthermore, the filmic concentration on the Germans as adversaries in the conflict shown corresponded to the Bolsheviks' constant interest in German politics and developments, while the Habsburg Empire had ceased to exist and the Austrians had turned into citizens of a small and weak state in the heart of Europe. Germany still played an important role in European politics and in Moscow's plannings; Austria and its mediocre Communist Party were only third-rate. ${ }^{83}$ It did not match with Bosheviks' "didactic" understanding of cinema to restore to life a "dead enemy," instead of dealing with an existing danger. ${ }^{84}$ Based on the films seen by the authoress of this article and due to the characterization of the films in Soviet journals, there can be no doubt that AustriaHungary in Soviet interwar feature films with references to the First World War has either completely vanished or left only vague traces. Furthermore, the remembrance of the First World War in general began to fade and then disappeared. Films that picked up the issue of World War One were considered to be behind the times and therefore needless.

Already at the end of the 1920s, the Communist Party attempted "to bring political order to Soviet cinema and direct it along a secure ideological path." Film productions had to answer Communist demands in regard to an adequate entertainment of the masses:

83 On the interwar relations between the Soviet Union and Austria see: Verena Moritz et al., Gegenwelten: Die österreichisch-sowjetischen Beziehungen 1918-1939 (St. Pölten: Residenzverlag, 2013).

84 Youngblood, A War Forgotten, 185. 
"Acknowledging the public's love of action, adventure and comedy, which they had become accustomed to through popular Soviet films and imported American and European films, it was stressed that movies should provide communist enlightenment, but in a form 'intelligible to the millions."'85 Finally, the Kremlin more and more insistently wanted cinematography to respond to the demands of the armed forces and defense, too. Since 1926/1927, the fear of imminent military attack strongly influenced Soviet perception of the world. Against this backdrop, Soviet authorities claimed the production of military feature films preparing the audience for a defensive warfare ${ }^{86}$ Cinematography abroad, asserted the journal Sovetskiy Ėkran had already begun its "war" against the USSR.$^{87}$ In 1930, in the journal Kino i zhizn' (Cinema and life), there were complaints about the passiveness of Soviet cinema in regard of themes like "the defense of our country" 88 Soviet cinema had to become one of the strongest organizers of the Red Army's future victory. ${ }^{89}$ Facing the threat of a future

85 Jamie Miller, Soviet Cinema: Politics and Persuasion under Stalin (London: Palgrave Macmillan, 2010), 16.

86 M. Korol', "Voennokhudozhestvennaia kinoproduktsiia," in Proletarskoe kino, no. 4 (April 1932): 35-42, here: 35; "Privet pervomu vsesoiuznomu soveshchaniiu rabotnikov voennooboronnoi kinemtografii: Vnimanie oborone - na pervoe mesto," in Proletarskoe kino, no. 8 (1932), 1-10; Mikhail Korokhin, Oborona SSSR i kino. Zametki o kino kak orudii proletariata $v$ voine budushchego (Moskva, 1930).

87 "Kak vooruzhaiut kinematografiiu protiv SSSR," in Sovetskij Ekran, no. 8 (Feb. 18, 1929): 14. "Obzor pechati," in Sovetskij Ekran, no. 30 (July 30, 1929): 9 .

88 "Kino i oborona," in Kino i zhizn', no. 16 (June 1, 1930): 7.

89 M. Sychev, "Kino na sluzhbe oborony SSSR," in Sovetskij Ekran, no. 30 (July 30, 1929): 5. 
conflict, cinema was called upon not to copy Western pacifism or neutralize the German-Soviet antagonism on behalf a proletarian solidarity, as Boris Barnet for Okraina was criticized. ${ }^{90}$ Even more abrasively attacked than Barnet was the director of Sniper, Semëon Timoshenko, whom M. Korol' in the journal Proletarskoe kino accused of having totally ignored whether his interpretation of the war was compatible with Lenin's doctrine in regard to warfare. Korol's comments on Timoshenko and his work were crushing. He argued that Timoshenko's mindset in fact had nothing to do with Marxism-Leninism and its attitude towards questions of peace and war. Sniper, he alleged, was an example of Western "Remarquism," completely neglecting the importance of class conflicts. ${ }^{91}$ Lewis Milestone's film adaptation of All Quiet on the Western Front was not shown "publicly" in the Soviet Union, ${ }^{92}$ but in a hypertrophic manner the movie served as example of Western mendaciousness in regard to pacifistic films. The Soviet people had to be indoctrinated that the only country that really wanted peace was, of course, the Soviet Union.

Various factors are responsible for the marginalization and, finally, the disappearance of World War I-related films from the Soviet screen in the 1930s. Karen Petrone in this connection refers to "many bureaucratic and ideological forces and economic constraints within the Soviet Union pushing against continued emphasis on

90 Youngblood, “A War Forgotten," 185; "Fi'lma i oborona," in Proletarskoe kino, no. 13 (October 1932): 3-5; V. Plonskij, “Zadachi teoreticheskoi raboty po voenno-oboronnoj fil'me," in Proletarskoe kino, no. 11 (September 1932): 28-31.

91 Korol', "Voennokhudozhestvennaia kinoprodukciia," 36.

92 Karen Petrone, The Great War in Russian Memory, 230. 
World War I." ${ }^{93}$ Propagandistic efforts to make Soviet people aware of future conflicts have to be taken into account in particular. World War One obviously was not suited for creating an unconditional readiness for war among Soviet people. The "imperialistic" conflict of the past could not give positive example of patriotic duty as it was required by the communist fatherland in the 1930s. When Soviet cinema made the transition to sound in this period, encapsulating and cutting off from the Western cinema, it was instructed to abandon the avant-garde practices of the 1920s and to accept the guidelines of socialist realism. Cinema had to create positive heroes and obedient citizens to support the course of the Communist Party and to defend the motherland against invaders. The most famous example of films that had to convey an optimistic type of patriotism was E. Dzigan's Esli zaftra voina (If War Comes Tomorrow), released in 1938. ${ }^{94}$

93 Ibid., 291. See also: Jamie Miller, "The Purges of Soviet Cinema, 1929-38," Studies in Russian and Soviet Cinema 1, no. 1 (2006): 5-26, accessed April 1, 2016, http://dx.doi.org/10.1386/srsc.1.1.5_1. On the perception of the First World War without a special hint at Soviet cinema between 1941 and 1945: "Space for history opened wider during World War II as the country mobilized to fight a people's war. The First World Imperialist War suddenly became World War I, the enemy was no longer international imperialism but German imperialism, and commemorative articles outlined the communalities between past German behavior and Nazi expansionism"; Cohen, “Oh, That!", 83.

94 Jamie Miller, Soviet Cinema, 16-19; A.V. Fediuk, "Sovetskaia sistema kinemtografa 1930gg.: Rol' chudozhestvennogo kino v agitacionno-propagandistskoi rabote Stalinskogo rezhima," in Problemy rossijskoj istorii, Vypusk 10 (Moscow: Magnitogorsk, 2010), 294-311, here: 294-296; S.V. Dobrashenko, Russkii sovetskii chudozhestvennyi fil'm v 1930-1934 godach (na materiale zvukogo kino), Avtoreferat dissertatsii, predstavlennoi na soiskanie uhenoi stepeni kandidata iskusstvovedceskikh nauk (Moscow 1952), 5. 
1945-2014

"The cataclysm of World War II forever changed the meaning and also the name of World War I in the Soviet Union as in the rest of Europe. In the last years of Stalin's reign, the overwhelming task of rebuilding the country despite the loss of perhaps as many as twenty-seven million people overwhelming eclipsed the remembrance of World War I." ${ }^{95}$ In fact, after 1945, attention to World War One was only sporadic. Soviet cinema was not an exception. As Alexandre Sumpf shows, only very few films, for instance, Agoniia (Agony, 1975, directed by Elem Klimov), referred to the Great War but did not put it in the center of interest. ${ }^{96}$ In addition, A.M. Belogor'ev quotes the TV drama Zhizn' Klima Samgina (Life of Klim Samgin), a 1986 adaption of Maksim Gor'kii's novel, Bumbarash (1971), told along with one of Arkadii Gaidar's early literary works; or Skorbnoe beschuvstvo (Mournful Unconsciousness, 1986, directed by Aleksandr Sukorov), a high-grade experimental adaption of George Bernard Shaw's play Heartbreak House, which because of its intransigence of (non-)narration probably met with no response among a broader audience. Besides, in 1987, Aleksandr Muratov adapted for screen a novel by Valentin Pikul'. According to Belogore' ev, Moonzund is the only film in the period between 1945 and the dissolution of the Soviet Union that really focused on the First World War, by showing the situation of the Russian navy at the Baltic Sea. Furthermore, Belogor'ev points to the film adaptations of Mikhail Sholokhov's Tikhii Don (And Quiet Flows the Don, 1957-1958 by Sergei Gerasimov and 1986-1992 by Sergei Bondarchuk) and Aleksei Tolstoi's Khozhdeniia po mukam (Life of suffering, 1957-1959 by Grigorii Roshalem and 1977 by Vasilii

95 Karen Petrone, The Great War, 282.

96 Alexandre Sumpf, La Grande Guerre oubliée: Russie, 1914-1918 (Paris: Perrin, 2014), 457. 
Ordynskii). In these films-rarely enough-Austrian soldiers and officers appear. The concept of the enemy however differs very much. In both adaptations of Tichii Don, the Austrian soldier who is killed by one of the central characters is more or less a victim of the circumstances, ${ }^{97}$ whereas in Roshalem's version of Tolstoy's novel the Austrians are characterized as tormentors of Russian prisoners of war. ${ }^{98}$

In the 1990s, Russian cinema turned to various themes and started to rethink also the Soviet past. Nikita Mikhalkov's Utomlënnye solntsem (Burnt by the Sun, 1994), for instance, depicted the fate of a senior Red Army officer and his family during the "Great Purges," and The Thief (1997, directed by Pavel Chukhrai) showed a young mother and her son's everyday struggle for survival in the late 1940s through the early 1950s. Finally, Russian cinema and TV discovered history before Russia had become communist. In doing so, Russian films followed the official course of a gradual rehabilitation of the Tsarist Empire, as well as its sovereigns and "servants"-if only so they could be introduced as patriots. Putin had "recognized the enormous potential of cinema" and, of course, also of TV "for nation building purposes"99 and for his patriotic campaign. As a result, history before the Bolshevik Revolution was integrated in a "patriotic re-interpretation" of Russian history as a whole.

97 Already in 1931, Olga Preobrazhenskaia had been criticized to blur the characters of the Austrian officer and Grigorii as well as of the Cosacks in general in her film Tichii Don (1931); See: J. Iukov, “Tichii Don," Proletarskoe kino, no. 10 (November 1931): 16-21.

98 A. M. Belogor'ev, "Pervaia mirovaia voina," 148-149.

99 Jasmijn Van Gorp, "National Identity in Post 9/11 Transnational Cinema: The Case of the Russian Blockbuster $9^{\text {th }}$ Company," in Postcommunist Film - Russia, Eastern Europe and World Culture: Moving Images of Postcommunism, ed. Lars Kristensen (London: Routledge, 2012), 13-23, here: 15. 
A lot of persons engaged in the cultural sector did and do support Putin's course. Nikita Mikhalkov, as one of Russia's lead filmmakers, contributed to the new approach to Russia's past, too. In his work, he addressed Russia in the turbulent period between the 1870s and 1930s. His "love of the military as a key producer of collective subjectivity" is manifested, for example, in Sibirskiy Tsiriul'nik (The Barber of Siberia, 1998), dedicated to "Russian officers, the pride of the Fatherland." ${ }^{100}$ The positive image of Tsarist officers replaced their damnation in the Soviet era. The restoration of Tsarist army's reputation was no longer taboo.

In 2005, Russian TV produced Gibel' imperii (The Fall of the Empire), a television series with 10 episodes, depicting the struggle of Tsarist military intelligence in the First World War and the role of intelligence officers after the caesura of 1917. German antagonists and, in very rare cases, Austrian spies and traitors figure only on the very margins of six episodes. The main characters, Russian intelligence officers and their families, are patriotic heroes and, finally, victims of unpatriotic evil, criminal revolutionaries and brutalized soldiers. Gibel' imperii brings a rehabilitation of Tsarist officers, insinuating that former social order was not that false: Officers do know what has to be done, soldiers don't, and beautiful middle -class women are morally and intellectually superior to superstitious and featherbrained house maids. The audience is confronted with a stirring drama of Russia's downfall and a tragic struggle of super-patriots to protect their home country from alien invaders and then, in 1917, from traitors to their own country. Andrei Kravchuk in the Admiral (2008) gives a similar interpretation of the war by presenting Admiral Kolchak as a superhero. The costly action film on Kolchak's fate made it quite

100 Nancy Condee, The Imperial Trace: Recent Russian Cinema (Oxford: Oxford University Press, 2009), 91-92. 
plain that the "white Admiral" was a real patriot who served Russia until his death. ${ }^{101}$

Batal'on'. Pervii Zhenskii. Bessmertnyi (Battalion, 2014, directed by Dmitrii Meshkiev), however, is the most impressive example of the Russia's recent interpretation of World War One. The film, produced by Fëdor Bondarchuk, was supported by official Russian authorities, including the Russian Military Historical Society. The latter had been reconstituted in 2012 by the President of Russia, "with the goal of consolidating the resources of the State and the Society for the study of Russia's Military-Historical past, facilitating the study of national military history and counteracting attempts to distort it, as well as to popularize the achievements of military-historical study, encourage patriotism, and raise the prestige of military service." ${ }^{102}$ According to this characterization by the Society itself, the film obviously had to correspond with the aims cited. Its Chairman, the ministry of culture, Vladimir Medinskii, on the occasion of the production of Battalion, said that WWI "has always been badmouthed." "We hope," he added, that the film "will restore some honor in the minds of the people about their motherland." 103

The story of Battalion is based on real events during WWI. It depicts the establishment of a battalion of female soldiers in the era of the Provisional Government by Maria Bochkareva. Facing chaotic

101 See: Karen Petrone, “'Now Russia returns its history to itself': Russia Celebrates the Centenary of the First World War," in Remembering the First World War, ed. Bart Ziino (London: Routledge, 2015), 207-222, 129-145, and 139.

102 Official site of the "Russian Military-Historical Society," accessed Feb. 7, 2016, http://histrf.ru/ru/rvio/rvio/English.

103 "Why is Russia Commemorating WWI With a Propaganda Film?", accessed Feb. 7, 2016, http://www.indiewire.com/article/why-is-russia-commemorating-wwi-with-a-propaganda-film-20140730. 
demobilization and the breakdown of the Western front, Bochkareva aimed to "save the motherland," left alone in its struggle for survival by soldiers "blinded by notions of false freedom." 104 Members of the military and administration in 1917 "were enthusiastic about the idea of a unit consisting of women, believing that female soldiers would have powerful propaganda value. They thought it would revitalize the downtrodden and fatigued male soldiers, shaming them into resuming combat duties." ${ }^{105}$ In fact, the battalion's impact on Russian warfare between February and October Revolutions was marginal. Still, the message of the film is obvious: To protect one's motherland is a "sacred duty," notwithstanding the prospects of success. Interestingly, most of the men shown on the screen, irrespective of whether they are Russian or German, are either cruel or primitive or cowardly and depraved. So, one can reason, the ideal "creature" of current Russian patriotic self-concept is half man half woman, and above all loyal. ${ }^{106}$ Putin's

104 M. Norris, “Dmitrii Meskhiev: Battalion (Batal’on, 2015),” kinokultura.com, accessed Feb. 6, 2016, http://www.kinokultura.com/2016/51rbatalion.shtml.

105 "Why is Russia Commemorating WWI With a Propaganda Film", accessed Feb. 7, 2016.

106 "Russia's women soldiers are repeatedly shown to be patriotic, they are willing to defend their motherland, they have the proper hatred for Russia's enemies, and they have the Orthodox faith. The male imperial officer class is divided, but ultimately patriotic too, particularly when several officers disobey the Soviet Military Committees by tearing off their epaulettes and joining the women. The Provisional Government, Kerensky in particular, is largely shown to be ineffective but relatively benign. The villains are the nasty German soldiers who employ chemical weapons and subterfuge and also, most significantly, the brutish, dirty, defeatist Russian soldiers who no longer want to fight. In the end, though, they too are redeemed somewhat by the patriotism of the Women's Battalion"; M. Norris, "Battalion." 
various statements on his understanding of patriotism, "as well as the patriotic education program documents, make clear that among the major indicators of loyalty to the state are military service and a pledge to defend the state." ${ }^{107}$

In Kino-Kultura, Stephen M. Norris wrote very critically about Battalion, which had disposed a budget of about ten million dollars. He highlighted the propagandistic mission of the production and the use of history as a, in fact, replaceable setting without any expedient information for the audience: "Meshkiev's Battalion does not delve into anything that might offer nuance or detract from its overall patriotic mythistory. We do not learn much about the Great War, why and where the Women's Battalion fought, or much about Bochkareva's backstory." ${ }^{108}$ So, it could not be a surprise that, once more, it was not of much importance for the filmmakers who fought against whom and for what reason. Nevertheless, the Germans are brutal and act perfidiously. It becomes evident that differences between the depiction of Germans in World War One and Germans in World War Two in Russian cinema dissolve. Austria-Hungary, however, is not even mentioned in Battalion.

As Stephen M. Norris, referring to Larisa Maliukova's review in the Novaia gazeta, concludes: The film "uses the past to bang out a message to contemporary audiences. Battalion is not a movie to watch if you want to 'see history' and learn anything about the Women's Battalion of Death in 1917. It is a movie to

107 Valerie Sperling, "Making the Public Patriotic: Militarism and Anti-militarism in Russia," in Russian Nationalism and the National Reassertion of Russia, ed. Marléne Laruelle (London: Routledge, 2010), 218-276, here: 258 .

108 Norris, "Battalion." 
watch if you want to see how contemporary patriotism gets articulated and mapped onto the past." ${ }^{109}$

To restore the Tsarist army's honor, and to show that there is reason for Russian people to be proud of its performance until the uprising of October 1917, was also a goal of various documentary films that were released on the occasion of the $100^{\text {th }}$ anniversary of the outbreak of the Great War.

Of course, these films do not get along without explaining the role of Austria-Hungary, especially in regard to the outbreak of the conflict. But, generally, the Habsburg state remains a dim something. Its army enters the scene only for some select moments. While, for instance, several Germany's military leaders are introduced by characterizing them as able, but also terrifying adversaries (for instance General August von Mackensen), the Austrian Chief of the General Staff General Franz Conrad von Hötzendorf is not even mentioned. Sporadically, soldiers of the Habsburg forces appear as POWs. The "great retreat" of Russian troops in 1915 as a result of German-Austrian offensive appears as "national tragedy." ${ }^{110}$ All the more, in those episodes of the production Istorija Rossija XX veka that are dedicated to the First World War, the filmmakers are above all interested in showing how bravely the Russians fought. The patriotic officers of the Tsarist army are cast as victims of unpatriotic revolutionaries. Russia's enemies were predominant only because of their technological and economic superiority, not in terms of the fighting spirit and the bravery of officers and soldiers as well. Western states, whether they were allies or enemies, appear as more or less morally rotten players. France and Great Britain succeed

109 Ibid.

110 Rossiia XX Vek. Pervaia Mirovaia Voina (Chasti 1 I 2); Pervaia Mirovaia Voina. 1914-1918 (2 DVD); Istoriia Rossii XX veka, fil'my 1-28. 
because of Russian soldiers' sacrifice. ${ }^{11}$ The Germans had ruthlessly attacked the Tsarist Empire, and the Danube monarchy is accused for having deported thousands of "Russians" (i.e., Ruthenen or Ukrainians) in various "death camps"-war crimes that were hushed by Western Europe until today. Actually, on the eve of World War I, the Austrian authorities had begun a wave of persecution against the Russophiles in Galicia. Hundreds were arrested and brought to camps in Austria. In the Thalerhof camp, approximately 2,000 internees died, most of them as a consequence of epidemics and horrendous living conditions. Only in recent years was the internment of so called "Russophiles" examined by Austrian historians. ${ }^{112}$ The death toll among internees, refugees, and POWs in Austria-Hungary was immense. The reasons are complex. The makers of the above-mentioned documentary film on World War One, however, were not interested in a balanced and differentiated analysis. They imply a conjunction of the fate of "Russian" people during World War One and Nazi mass murders. Furthermore, the audience learns that the "Ukrainian people" was a propagandistic invention

111 This interpretation was widespread already during the war. Even Austro-Hungarian secret service officers reported on this topic and stressed the impression that Russia blamed its allies for defeat and the high number of dead soldiers among Russian troops; see: Albert Pethö, Agenten für den Doppeladler: Österreich-Ungarns Geheimer Dienst im Weltkrieg (Graz: Leopold Stocker Verlag, 1998), 79.

112 Hannes Leidinger et al., Habsburgs Schmutziger Krieg: Ermittlungen zur österreichisch-ungarischen Kriegsführung 1914-1918 (St. Pölten: Residenz Verlag, 2014); Georg Hoffmann, Nicole-Melanie Goll, and Philipp Lesiak, Thalerhof 1914-1936: Die Geschichte eines vergessenen Lagers und seiner Opfer (Herne: Schäfer, 2010). 
of Russia's enemies, ${ }^{113}$ and that there is only a minor difference between the crimes of Nazi Germany in the Second World War and the oppression Russians (not Ukrainians!) suffered in the First World War. The production, which was financially supported by Russian Orthodox Church, intends to unmask a Western Europe that is only ironically called "civilized." The anti-Western and anti-Semitic tenor is unmistakable. Experts of the "Russian Institute for Strategic Studies," established by the President of the Russian Federation, present a narrative of World War One that outlines why present-day Russia must be aware of-that is the message-Western Europe's presumptuousness and contempt of Russian people. One can read this interpretation of Russia's role in the First World War as advising self-isolation and retreat to a "better," namely a "Russian," world.

In general, the remembrance of the First World War in recent Russian feature and documentary films ${ }^{114}$ exhibits "aspects of émigré military commemorative practice," namely "the prominence of religion and the Orthodox Church," the "valorization" of the imperial army ${ }^{115}$ and a certain nostalgia for the Romanov monarchy. This combination, however, is complemented by a mixture of Soviet paradigms and recent re-interpretations. The emphasis on Soviet-German antagonism and the alienation from the former allies, followed by a complete discord among the

113 Putin shares this statement. On occasion of the war in the Ukraine he said: "I consider Russians and Ukrainians generally to be one people"; see "Russian Orthodox Church Lends Weight to Putin Patriotism," BBC, accessed Feb. 8, 2016, http://www.bbc.com/news/world-europe-33982267. 114 A special approach to WWI was chosen by the makers of the documentary film Do voiny ja byl malen'kim (Before the War I Was Young), produced in 2006 on Russian child soldiers during World War One.

115 Cohen, “Oh, That!”, 85. 
former partners, undoubtedly are perseverative narratives. Today, World War I is not a "war forgotten" in Russia, but a war "transformed": defeat has been turned into victory. The current official Russian notion that "victory is tied very closely to an emerging" or already emerged and prevailing "view of the war as a heroic one in which Russian soldiers fought valiantly and demonstrated 'mass heroism. This stands in contrast both to long-standing Western notions that the Russian soldier fought poorly in the First World War and Soviet claims that after a very brief period of chauvinistic fervour, the Russian soldier refused to fight." ${ }^{116}$ Russian fictional and documentary films have processed these notions and generated representations of war as tools for a patriotic re-interpretation of the Tsarist Empire's last war. Lacking a plausible utility in terms of being relevant for present Russia's politics, the "deceased Dual Monarchy" in this conception can easily be neglected or even forgotten.

116 Petrone, “'Now Russia Returns Its History to Itself,” 134. 